\title{
RESEARCH
}

Open Access

\section{Short-wave enhances mesenchymal stem cell recruitment in fracture healing by increasing HIF-1 in callus}

\author{
Dongmei Ye ${ }^{1 *+} \mathbb{D}$, Chen Chen ${ }^{2+}$, Qiwen Wang ${ }^{1,3}$, Qi Zhang ${ }^{1}$, Sha Li ${ }^{1}$ and Hongwei Liu ${ }^{1}$
}

\begin{abstract}
Background: As a type of high-frequency electrotherapy, a short-wave can promote the fracture healing process; yet, its underlying therapeutic mechanisms remain unclear.

Purpose: To observe the effect of Short-Wave therapy on mesenchymal stem cell (MSC) homing and relative mechanisms associated with fracture healing.

Materials and methods: For in vivo study, the effect of Short-Wave therapy to fracture healing was examined in a stabilized femur fracture model of 40 SD rats. Radiography was used to analyze the morphology and microarchitecture of the callus. Additionally, fluorescence assays were used to analyze the GFP-labeled MSC homing after treatment in 20 nude mice with a femoral fracture. For in vitro study, osteoblast from newborn rats simulated fracture site was first irradiated by the Short-Wave; siRNA targeting HIF-1 was used to investigate the role of HIF-1. Osteoblast culture medium was then collected as chemotaxis content of MSC, and the migration of MSC from rats was evaluated using wound healing assay and trans-well chamber test. The expression of HIF-1 and its related factors were quantified by q RT-PCR, ELISA, and Western blot.

Results: Our in vivo experiment indicated that Short-Wave therapy could promote MSC migration, increase local and serum HIF-1 and SDF-1 levels, induce changes in callus formation, and improve callus microarchitecture and mechanical properties, thus speeding up the healing process of the fracture site. Moreover, the in vitro results further indicated that Short-Wave therapy upregulated HIF-1 and SDF-1 expression in osteoblast and its cultured medium, as well as the expression of CXCR-4, $\beta$-catenin, F-actin, and phosphorylation levels of FAK in MSC. On the other hand, the inhibition of HIF-1 a was significantly restrained by the inhibition of HIF-1a in osteoblast, and it partially inhibited the migration of MSC.
\end{abstract}

Conclusions: These results suggested that Short-Wave therapy could increase HIF-1 in callus, which is one of the crucial mechanisms of chemotaxis MSC homing in fracture healing.

Keywords: Mesenchymal stem cells, Short-Wave therapy, Recruitment, Fracture, HIF-1

\footnotetext{
*Correspondence: shuiyan_1980@163.com

${ }^{\dagger}$ Dongmei Ye and Chen Chen contributed equally to this work.

'Department of Rehabilitation, Affiliated Zhongshan Hospital of Dalian University, Dalian 116001, China

Full list of author information is available at the end of the article
}

(C) The Author(s). 2020 Open Access This article is licensed under a Creative Commons Attribution 4.0 International License, which permits use, sharing, adaptation, distribution and reproduction in any medium or format, as long as you give appropriate credit to the original author(s) and the source, provide a link to the Creative Commons licence, and indicate if changes were made. The images or other third party material in this article are included in the article's Creative Commons licence, unless indicated otherwise in a credit line to the material. If material is not included in the article's Creative Commons licence and your intended use is not permitted by statutory regulation or exceeds the permitted use, you will need to obtain permission directly from the copyright holder. To view a copy of this licence, visit http://creativecommons.org/licenses/by/4.0/ The Creative Commons Public Domain Dedication waiver (http://creativecommons.org/publicdomain/zero/1.0/) applies to the data made available in this article, unless otherwise stated in a credit line to the data. 


\section{Introduction}

Fracture healing is a biologically optimized process. Mesenchymal stem cells (MSCs) are multipotent stromal cells that can differentiate into multiple cell types such as chondrocytes and osteocytes and thus have an essential role in the bone healing process [1]. While fracture healing, circulating MSC can receive signals from the injured tissue and migrate to the damaged sites. Over the last decade, several strategies for fracture healing have been investigated, including the stimulation of endogenous stem cell populations from the mature body [2, 3]. An alternative strategy is the use of exogenous stem cells, which can be obtained from connective tissues and are controlled by the expression of molecules during MSC expansion, such as CXCR4 and complement 1q (C1q) $[4,5]$, or by certain chemicals [6], such as valproate or lithium, which are involved in MSC homing and can trigger the expression of certain key factors. Since the mobilization is a kind of directional migration, both endogenous and exogenous MSC recruitment is related to the condition of the fracture site. Currently, researchers are focusing on improving the condition of MSC recruitment by using biological agents. Clinicalstandard platelet products loaded membranes [7] and naringin [8] successfully support MSC colony formation and promote MSC migration in vitro. Furthermore, MSC migration can be improved under hypoxic conditions. Previous studies have suggested that hypoxic conditions decrease the MMP secretion and increase CXCR4 expression $[9,10]$. However, the effect of physical agency therapy on MSC migration has not received adequate attention.

Short-Wave therapy is a type of high-frequency electrotherapy, which can promote the fracture healing process $[11,12]$. At high frequencies, the electromagnetic energy is converted to thermal energy, which can induce heat (temperature over $40{ }^{\circ} \mathrm{C}$ ) to the treated area of the body [13], where the heating process affects blood flow [14] and decreases pain [15]. Accumulating evidence has indicated that both hypoxia and hypoxiadriven angiogenesis can be regulated by thermal therapy [16]. The hypoxia-inducible factor (HIF) involved signaling pathway is activated under hypoxia. HIF protein, especially HIF- $1 \alpha$, has been associated with MSC migration and differentiation [17]. As a critical transcriptional regulator, HIF-1 can regulate the expression of multiple cytokines, such as stromal cell-derived factor 1 (SDF-1) [10, 18] and focal adhesion kinase (FAK) [19], which has a central role in the adaptation of MSC to hypoxia $[20,21]$.

The present study explored the effects of Short-Wave therapy on HIF-1 expression in fracture and MSC recruitment from peripheral blood during fracture healing. Accordingly, we applied Short-Wave treatment on the fracture in the animal model and assessed the healing of fracture using the radiographs. Also, in vivo bioluminescent assays and callus histo-immunofluorescence were applied to evaluate the MSC migration. HIF-1 and related factors were also detected. siRNA targeted HIF- $1 \alpha$ was transfected to clarify its effect in Short-Wave therapy (Fig. 1). This study aimed to investigate the impact of Short-Wave therapy on MSC recruitment and explore the underlying mechanisms of Short-Wave therapy on fracture healing.

\section{Materials and methods}

\section{MSC isolation and identification}

MSC was isolated from femurs of 3-week-old male SD rats, as previously described [22]. Before performing any experiment, cells were passaged for 3 to 6 times. The surface marker expressions of MSC, including CD90, CD44, CD34, CD45, and CD11b/c, were analyzed by flow cytometry assay, as described in the previous study $[23,24]$.

\section{Animal grouping}

A total of 40 male SD rats, 8-12 weeks old, weighing 350-500 g, were obtained from Laboratory Animal Center of Dalian Medical University, China. Rats were housed in an environment with a temperature of $22 \pm$ $1{ }^{\circ} \mathrm{C}$, a relative humidity of $50 \pm 1 \%$, and a light/dark cycle of $12 / 12 \mathrm{~h}$.

After 1 week of adaptation, 40 SD rats were accurately weighed and randomly divided into two groups $(n=20 /$ group): Short-Wave treatment group (SW) and control group (Con). All rats underwent surgery to establish the femoral shaft fracture and intramedullary fixation model.

For in vivo bioluminescent assays to the MSC homing, 20 nude mice of femoral shaft fracture were injected MSC labeled by the GFP (MG) and then randomly divided into two groups, including a Short-Wave treatment group $(\mathrm{MG}+\mathrm{SW})$ and a control group (MG) ( $n=10 /$ group).

\section{Stabilized fracture model}

Stabilized right femur fractures were established by intramedullary fixation in 8-12-week-old male SD rats. A $0.25-\mathrm{mm}$ titanium alloy pin was inserted inside the medullar canal of the femur. A three-point bending device was then used to produce closed fractures of the femoral shaft with a standardized force [25]. In 20 male nude mice, transverse osteotomy with a $1-\mathrm{mm}$ bone fracture was created in the middle of the right femur in the same way. Buprenorphine was subcutaneously administered $(0.5 \mathrm{mg} / \mathrm{kg})$ for pain control.

\section{Cell injection}

All the 20 nude mice received injections with $5 \times 10^{6}$ / $50 \mu \mathrm{l}$ GFP-labeled MSC (MG) (C57BL/6 mouse strain) 


\section{In Vitro Experiments}

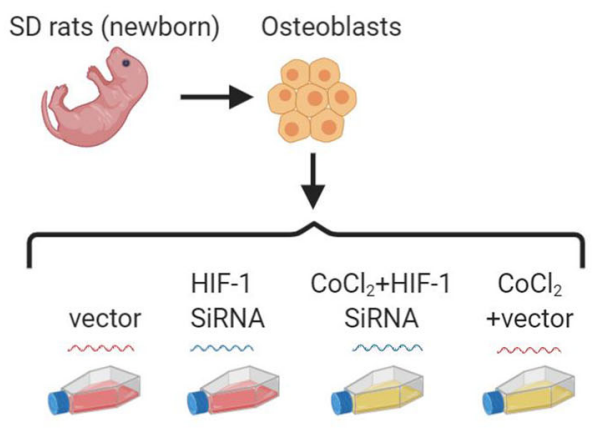

short wave short wave short wave short wave

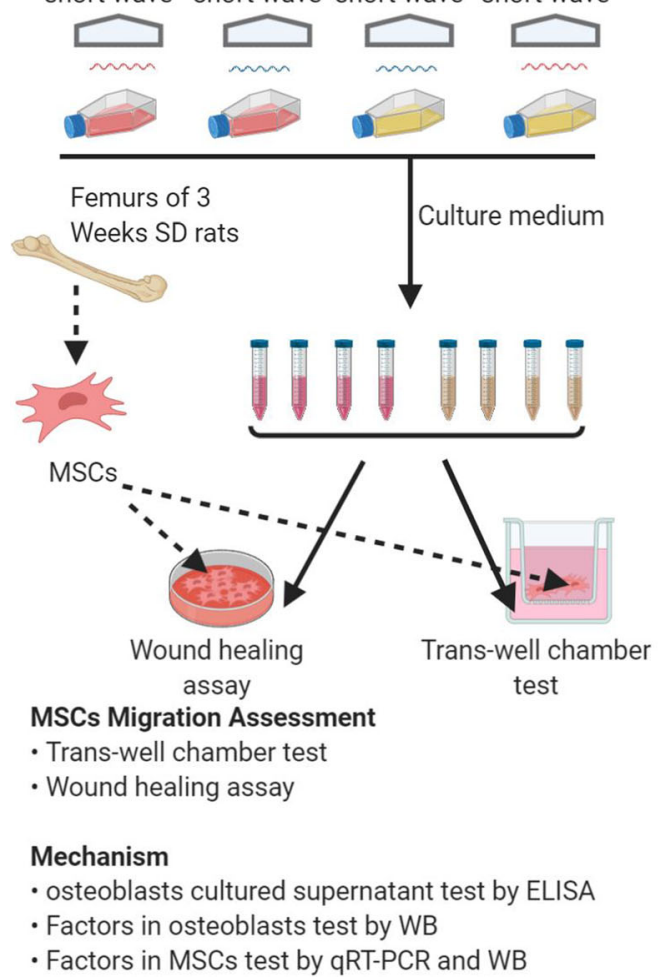

\section{In vivo Experiments}

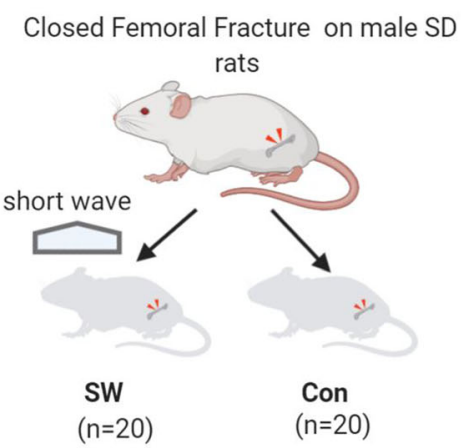

Fracture Healing Assessment

- Anteroposterior radiographs $(0 \mathrm{~d}, 7 \mathrm{~d}$,

14d, 21d, 28d)

- MicroCT Analysis (14d, 28d)

\section{Mechanism}

- Factors expression in callus by qRT-PCR (3d, 7d, 14d)

- Factors in plasma by ELISA(3d, 7d, 14d)

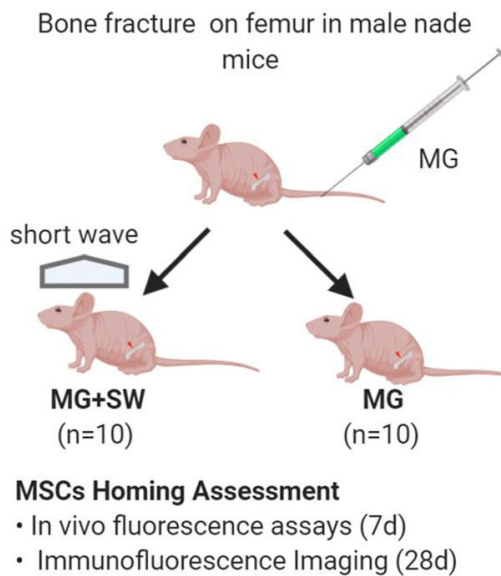

Fig. 1 Flowchart of the study design. Stabilized femur fractures were established in 40 SD rats. Radiographs and micro-CT analysis examined the effect of Short-Wave on fracture healing. The expression of HIF-1 and other factors in callus was tested by q RT-PCR. SDF-1 in plasma was evaluated by ELISA. To analyze the MSC migration in healing, in vivo fluorescence assays and immunofluorescence were used after treatment in 20 nude mice with a femoral fracture. For in vitro study, osteoblast simulated fracture site was first irradiated by the Short-Wave; $\mathrm{CoCl}_{2}$ in medium stimulated hypoxia condition; siRNA targeting HIF-1 was used to investigate the role of HIF-1. Osteoblast culture medium was then collected as chemotaxis content of MSC, and the migration of MSC was evaluated using wound healing assay and trans-well chamber test. The expression of HIF-1 and its related factors were quantified by q RT-PCR, ELISA, and Western blot. SW Short-Wave treatment, MG GFP-labeled MSC. The image element in the flowchart mainly comes from https://app.biorender.com/

(CYAGEN Company, China) 3 days after the femoral fracture. Cells were injected by tail vein using a microinjector.

\section{Short-Wave treatment}

Three days after the operation, Short-Wave therapy was applied in the Short-Wave treatment group. Briefly, animals were fixed in an apparatus so that they could not turn around. The treatment regimen was applied to the right thigh. The Short-Wave generator operated at a frequency of $27.12 \mathrm{MHz}$. A micro-heat continuous-wave Short-Wave exposure for $10 \mathrm{~min}$ was applied once a day. A similar procedure was carried out in the control group; however, the device was turned off.

For the in vitro study, the isolated rat osteoblasts in the treatment group underwent Short-Wave irradiation. 
The protocol of Short-Wave therapy irradiation on cells was based on a previous research [26]. The two noncontact applicators were of perpendicular contraposition and $10 \mathrm{~cm}$ away from each other. The cell culture flask was placed in the middle of the applicators. A micro-heat continuous-wave Short-Wave exposure for $90 \mathrm{~min}$ was applied twice on day 1 in the open air at $37^{\circ} \mathrm{C}$. The control group received a sham Short-Wave treatment by turning off the Short-Wave generator. On day 2, the culture medium from each group was collected for HIF-1 and SDF-1 protein-level analysis, and the medium was used in MSC cell wound healing assay and trans-well chamber test.

\section{Radiographic assessment}

The fracture healing was assessed by plain anteroposterior radiographs at days $7,14,21$, and 28 . The same Xray machine and settings were used for all radiographs every 7 days after fracture. Bone defects were analyzed using X-ray software.

Micro-CT scanning was performed to assess callus. Quantification for the volumes of the bony calluses as determined as previously described $[27,28]$. The region of interest was set within $800 \mu \mathrm{m}$ (50 slices) around the defect edge. We applied a fixed threshold of less than 330 for new calcified cartilage or unmineralized cartilage. Three-D microstructural image data were reconstructed by Inveon Research Workplace software. After $3 \mathrm{D}$ reconstruction, bone volume fraction $(\mathrm{BV} / \mathrm{TV})$ was automatically determined to confirm fracture healing.

\section{In vivo fluorescence assays}

Ten nude mice per group received anesthesia and were examined by the IVIS imaging system at day 7 after the surgery. The identical parameter settings were used for all samples: $f$ number 1 , field of view 22 , binning factor 18, and luminescent exposure (seconds) 10. The IVIS imaging examination and rates of photons were calculated and performed according to methods reported in a previous study [29].

\section{Histological analysis and immunofluorescence imaging}

Twenty nude mice (MG: $n=10$, MG + SW: $n=10$ ) were sacrificed for histological analysis and immunofluorescence imaging at day 28 after the operation. The femoral bone of nude mice and rats were sectioned, preserved, decalcified, and embedded in paraffin along the longitudinal axis. For morphological analysis, $5-\mu \mathrm{m}$ slices were sectioned, deparaffinized, and stained using hematoxylin and eosin. The immunofluorescence staining was performed as previously described [30]. Tissue slides of nude mice were stained with antibodies (A0516, Beyotime, China) against GFP to track exogenously delivered MSC labeled by GFP. A four-channel confocal laser scanning microscope was used to analyze all the samples. GFP- positive cells were automatically counted in five fields on $\times 100$ magnification by ImageJ software.

\section{Enzyme-linked immunosorbent assay (ELISA)}

The plasma of SD rats received by heart puncture at days 3,7 , and 14 after the operation $(n=4 /$ group/time point). The concentration SDF-1 in plasma of SD rats was analyzed using citrulline ELISA kit (CSB-E13414r, Cusabio Biotech, China). In culture media of osteoblasts (SD rat strain), the concentration of HIF-1 (SEA798Ra, USCN, China) and SDF-1 (SEA122Ra, USCN, China) content was also detected using the ELISA kit.

\section{Quantitative reverse transcription-polymerase chain reaction (q $R T-P C R$ )}

Callus of sacrificed SD rats was collected and snapfrozen in liquid nitrogen at days 3, 7, and 14 after the operation ( $n=4 /$ group/time point). RNA isolation and subsequent cDNA synthesis (Bio-Rad, 170-8891) were performed as previously described [31]. A total of $50 \mathrm{ng}$ of cDNA was amplified with custom-designed q RTPCR primers (Table 1). A melt curve was generated to analyze the purity of amplification products. The expression levels of mRNA were normalized to the average of $\beta$-actin. Relative expression of mRNA was evaluated by using the comparative CT method $(\Delta \Delta \mathrm{Ct})$ [32].

\section{Osteoblast culture and identification}

Osteoblasts were obtained from calvaria of 1-day-old neonatal SD rats using the method of collagenasepancreatic enzyme digestion as detailed in reference [33]. After two passages, alkaline phosphatase staining was utilized to identify the osteoblast cells.

\section{Small interference RNA transfection}

We inhibited HIF- $1 \alpha$ expression by siRNA in osteoblasts (SD rat strain). Synthetic siRNA oligonucleotide specific for HIF-1 $\alpha$ (NM_024359) (5' to 3': UUUAUCAAGA UGGGAGCUCTT) and nontargeting siRNA were obtained from Sangon (Shanghai, China).

Table 1 Oligonucleotide product size and accession numbers for q RT-PCR

\begin{tabular}{lll}
\hline Gene & Product size & Accession number \\
\hline HIF-1 & 105 & NM_021704 \\
SFD-1 & 126 & NM_001033 \\
FAK & 130 & NM_013081 \\
F-actin & 127 & NM_001109 \\
CXCR4 & 116 & NM_009911 \\
$\beta$-catenin & 155 & NM_053357 \\
$\beta$-actin & 103 & NM_007393 \\
\hline
\end{tabular}




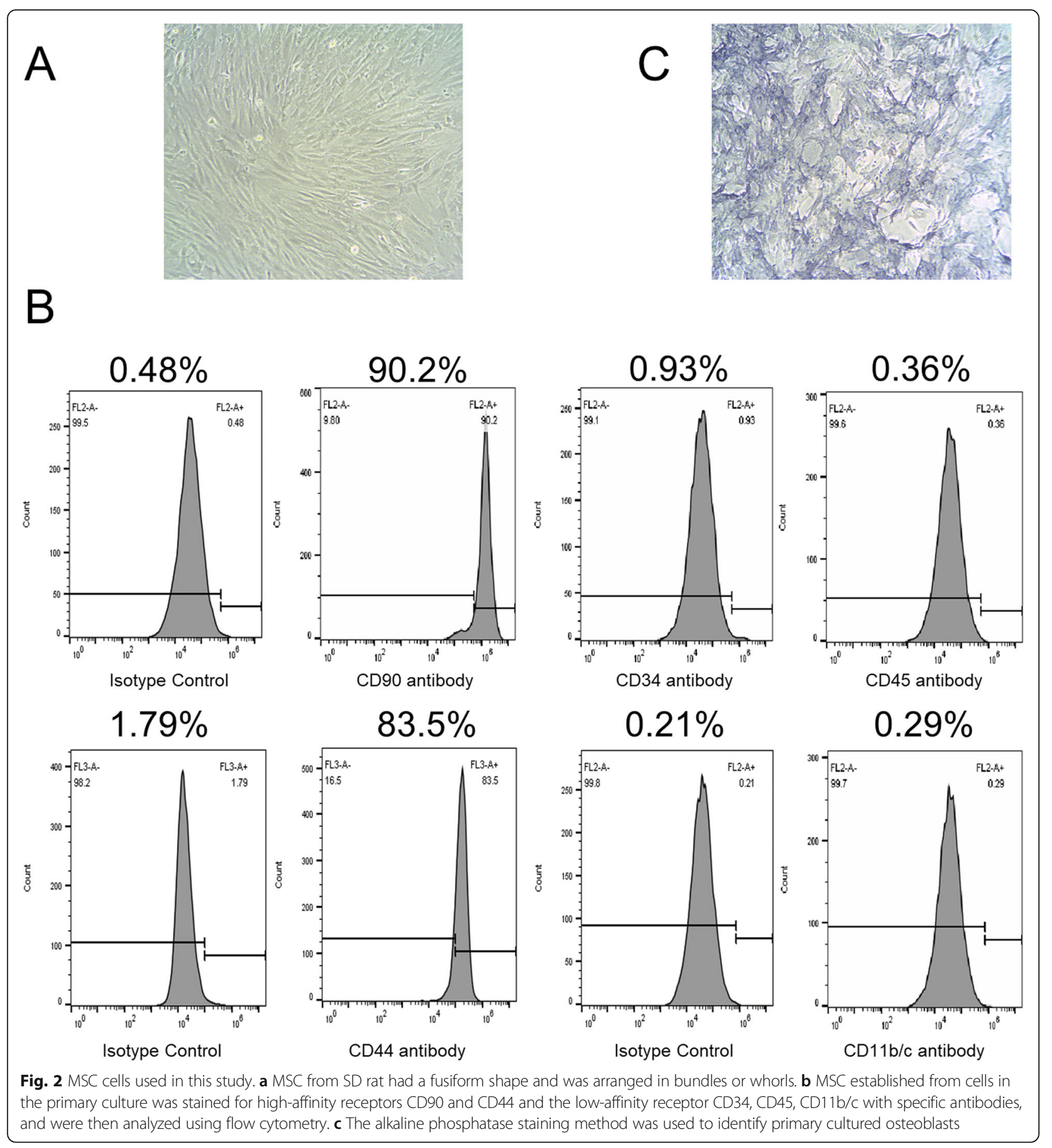

\section{Osteoblast culture medium}

Osteoblasts (SD rat strain) were seeded in 6-well plates for $24 \mathrm{~h}$ to $80-90 \%$ confluence. Three kinds of interventions were provided: (1) Short-Wave continuous irradiation for $180 \mathrm{~min}$, (2) $200 \mu \mathrm{mol} / \mathrm{l} \mathrm{CoCl}_{2}$-stimulated hypoxia condition in fracture, and (3) siRNA inhibition of HIF-1 $\alpha$. Eight kinds of osteoblast culture mediums were obtained from single or combined interventions for the follow-up experiment (Fig. 1).

\section{Wound healing assay}

MSC (SD rat strain) was cultured on 6-well plates to confluency and monolayers and wounded with a sterile 200- $\mu$ l pipette tip. The cultures were washed with PBS to remove detached cells and stimulated with 8 kinds of 

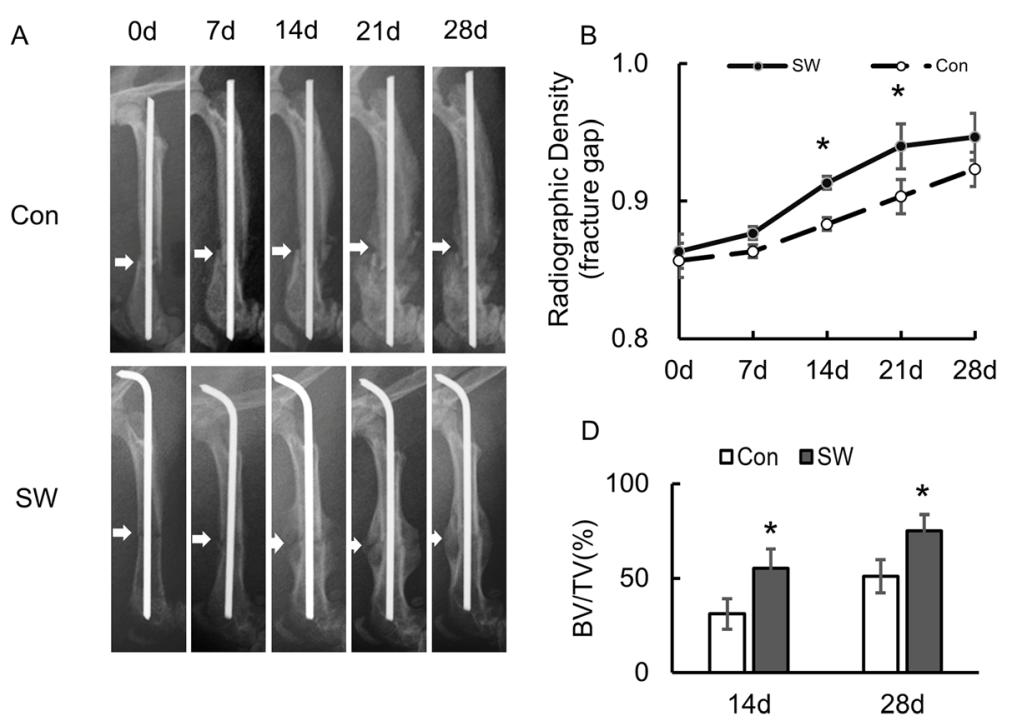

C

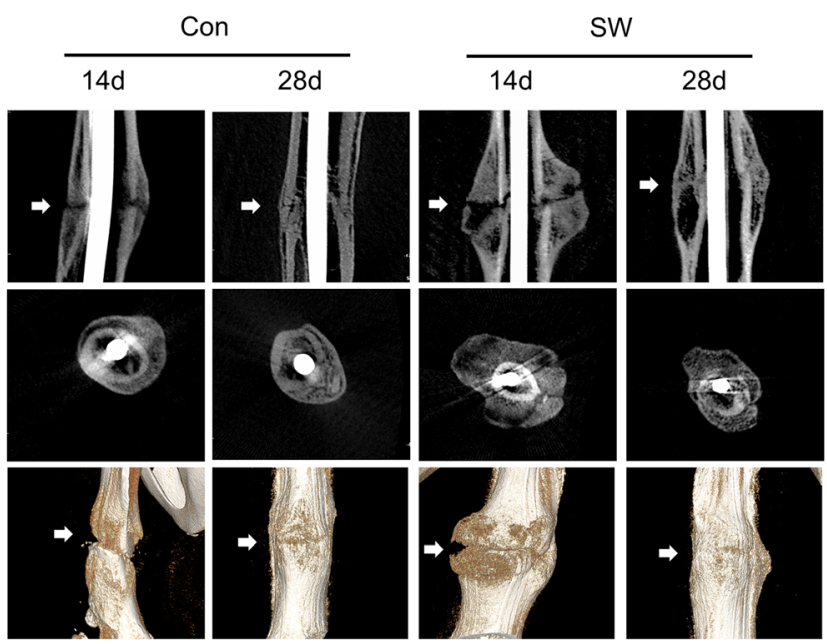

Fig. 3 Radiographs and micro-CT of the femur. a Radiographs of SD rat's femur. Callus formation was seen in the control group as well as in the SW group ( $n=4 /$ group). b The normalized radiographic density of the femur in control and different treatment. The higher radiographic density turned out in the SW group at day 14 and day 21 post-operation. After 28 days, no obvious fracture gap was found in each group. c Micro-CT images of the fracture (SD rats). More callus and narrow gaps were seen in the SW group at day14 ( $n=4 /$ group). d Analysis of ROI bone volume fraction (BV/TV) in the control and SW groups. Arrows in a and $\mathbf{c}$ represent fractures. Data represent mean \pm SD. Differences were assessed on each day by performing one-way ANOVA. ${ }^{*} P<0.05$. Con control, SW Short-Wave treatment

osteoblast culture medium fluid $1.5 \mathrm{ml}$ in each well. Photographs were collected at 0,24 , and $48 \mathrm{~h}$.

\section{Trans-well chamber test}

The tests were performed in Boyden Chambers (Corning, 3422, Lowell, MA). Eight kinds of osteoblast (SD rat strain) culture medium were seeded in the bottom chamber. The top chambers filled with MSC (SD rat strain) starved overnight were inserted. Twenty-four hours later, inserts were removed and washed. The cells that migrated to the bottom side were accumulated.

\section{Western blotting}

Osteoblasts and MSC cell (both are SD rat strain) lysates were prepared, and western blots were performed as previously described [34]. The $30 \mu \mathrm{g}$ of protein was loaded in each lane for reducing electrophoresis. Primary antibodies were used for $\beta$-actin (Sigma; A2228) diluted 1:10000, HIF-1 $\alpha$ (Gene Tex; GTX127309) diluted 1:2000, SDF-1 (CST; 3740) diluted 1:1000, FAK (Sangon Biotech; D160324) diluted 1:3000, phosphor-FAK (Sangon Biotech; D160324) diluted 1:2000, F-actin (Abcam; Ab205) diluted 1:2000, $\beta$-catenin (wanleibio; WL0962a) diluted 1:500, and CXCR4 (Abcam; ab124824) diluted 1:1000. 


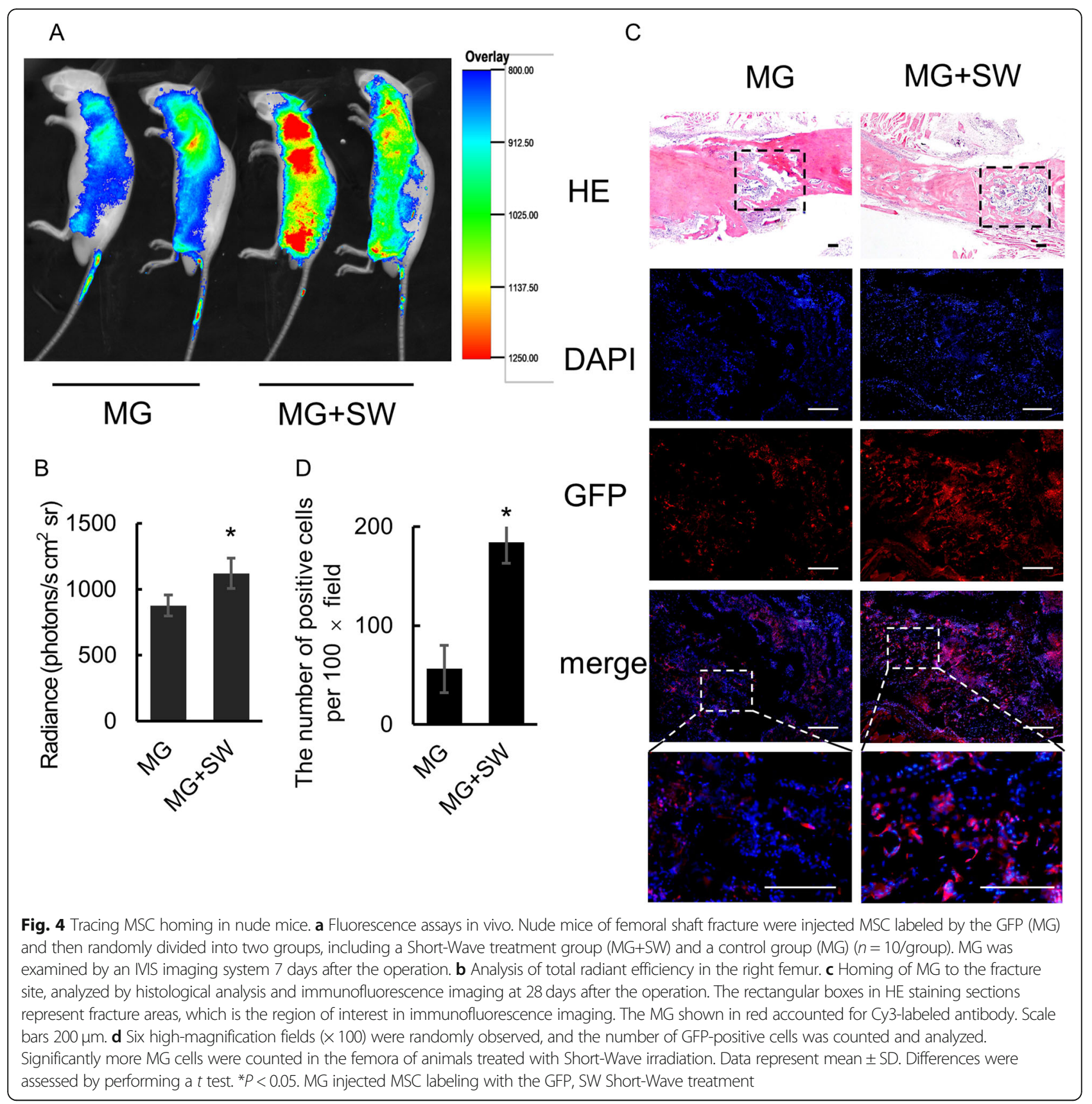

\section{Statistical analysis}

Statistical analysis was performed by SPSS 22.0 for Windows (SPSS, Chicago, USA). The results are shown as the mean value \pm standard deviation. The differences between groups were analyzed by $t$ test or analysis of variance (ANOVA). Two-tailed $P$ values were computed, and $P<0.05$ was considered to be statistically significant.

\section{Results}

\section{MSC identification}

After 3 to 6 passages, MSCs extracted from SD rats were in fusiform shape, arranged in bundles or whorls (Fig. 2a).
The results of flow cytometry demonstrated that over $90.2 \%$ and $83.5 \%$ of the mononucleated cell colonies isolated from the bone marrow of SD rats were positive for fibroblastic marker CD90 and MSC marker CD44, respectively, and negative for hematopoietic lineage markers (CD45 and CD11b/c) and the endotheliocyte lineage marker CD34 $(0.36 \%, 0.29 \%$, and $0.93 \%$, respectively) (Fig. 2b).

\section{Short-Wave treatment enhancing fracture healing}

To examine the role of Short-Wave treatment and MSC during fracture repair, we generated a closed 

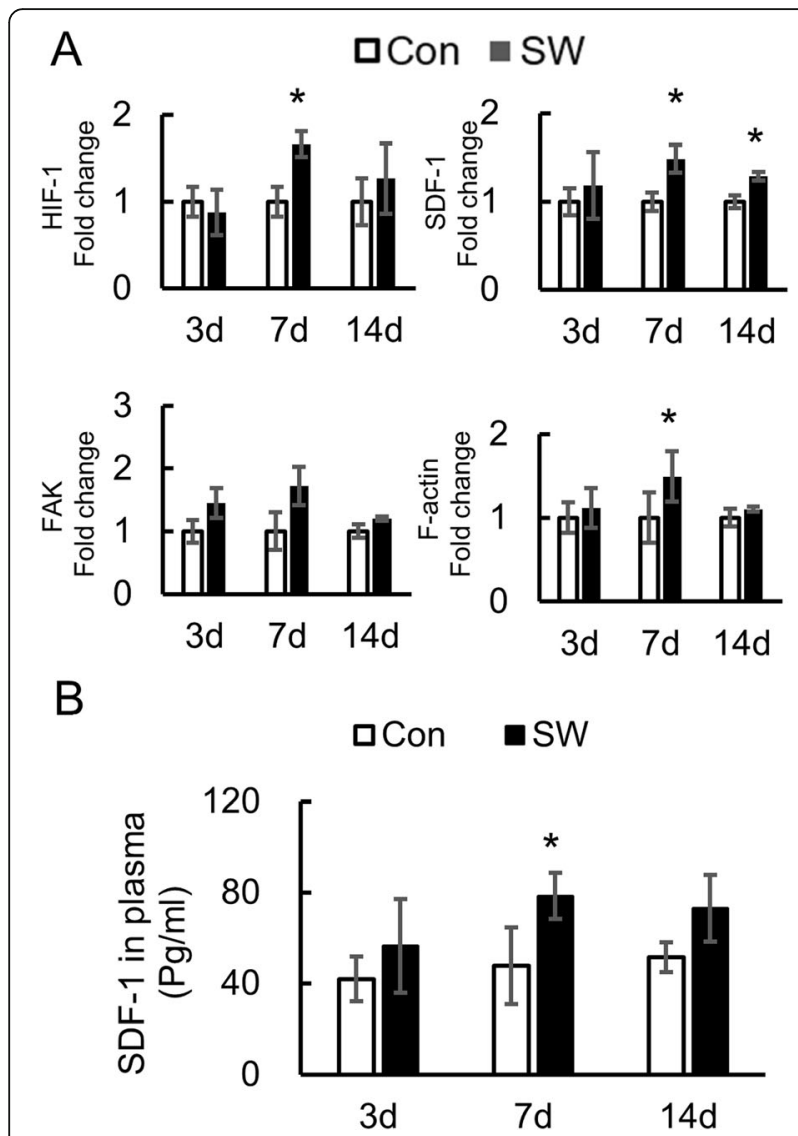

Fig. 5 Factors' expression in vivo. a Callus of sacrificed SD rats was collected at days 3, 7, and 14. The expression of HIF-1, SDF-1, FAK, and Factin in callus tissue detected by q RT-PCR ( $n=4 /$ group/time point). $\mathbf{b}$ The concentration of SDF-1 in plasma of sacrificed SD rats detected by ELISA at days 3, 7, and 14 ( $n=4 /$ group/time point). Data represent mean $\pm S D$. Differences were assessed among the four groups on each day by performing one-way ANOVA. ${ }^{*} P<0.05$. Con control, SW Short-Wave treatment

femoral shaft fracture model. Radiographic examinations showed a normal bone healing process in all rats. The radiographic analysis demonstrated that the SW group showed better fracture healing than the control group (Fig. 3a). Besides, the quantitative measurement density of the fracture gap showed that SW groups were significantly larger than the control group at days $14 \quad(P=0.033)$ and $21 \quad(P=0.026)$. Nevertheless, no significant difference was found between days $7(P=0.152)$ and $28(P=0.163)$ (Fig. 3b).

Micro-CT analysis showed that a more significant amount of bony callus was found in the SW groups than in the control group. Three-D reconstructed micro-CT images on day 14 and 28 post-fracture are shown in Fig. 3c. Comparing with the control group, the bone volume fraction $(\mathrm{BV} / \mathrm{TV})$ in the SW group was significantly higher at day $14(P=0.045)$ and day $28(P=0.049)$ (Fig. $3 \mathrm{~d})$.
Short-Wave therapy treatment promoting MSC homing in vivo

Nude mice were injected with MSC expressing the GFP report gene for observation of the MSC homing to the fracture. IVIS imaging system recorded radiant efficiency in the leg at day 7 post-operation. Higher cell migration was more common in animals receiving Short-Wave irradiation with total radiant efficiency $[\mathrm{p} / \mathrm{s}] /\left[\mu \mathrm{W} / \mathrm{cm}^{2}\right]$ compared to those not exposed to wave irradiation $(1123.1 \pm 116.0$ vs $878.2 \pm$ 79.2, $P=0.023$; Fig. 4a, b). Besides, GFP distribution analysis showed that MSC was not uniformly distributed throughout the body and tended to migrate to organs such as the lung, liver, and tail, which was observed in both groups.

Next, we quantified the homing of exogenously delivered MSC to the fracture site by using immunofluorescent staining and histological analysis. All the nude mice were sacrificed, and the callus tissues were prepared for immunofluorescence staining at day 28 after the operation. Significantly more MG cells were counted in the femora of animals treated with Short-Wave irradiation (GFP-positive cells per $\times 100$ field $56.3 \pm 26.8$ vs $184.3 \pm 21.2, \quad P=0.003$; Fig. 4c, d).

\section{Short-Wave therapy changes the gene expression in callus}

The results above indicated that Short-Wave therapy enhanced MSC migration to the fracture. Low oxygen occurs in the fracture following bony injury [35]. Therefore, the involvement of HIF-1 and its related factors (SDF-1, F-actin, and FAK) were investigated after Short-Wave therapy using q RT-PCR. No significant differences in HIF-1 were detected between the two groups at day $3(P=0.706)$ and $14 \quad(P=$ $0.602)$ post-therapy, yet its expression significantly increased in the SW group at day 7 compared to the control group $(P=0.002$; Fig. 5a). Moreover, compared with the control group, the expression of SDF1 increased in the SW group on days $7(P=0.044)$ and $14(P=0.016)$. In addition, a significant increase of F-actin was found at day 7 in the SW group $(P=$ $0.038)$, while there was no difference at day $3(P=$ $0.728)$ and day $14(P=0.835)$. For FAK, it seemed that Short-Wave therapy led to increases on days 3 and 7; nevertheless, there was no statistical difference between the two groups at day $3(P=0.051)$, day $7(P=0.142)$, and day $14(P=0.287)$.

In addition, SDF-1 in plasma was detected by ELISA (Fig. 5b). After 7 days of treatment with Short-Wave therapy, SDF-1 was increased by 1.5 -folds compared to the control group $(P=0.044)$. 

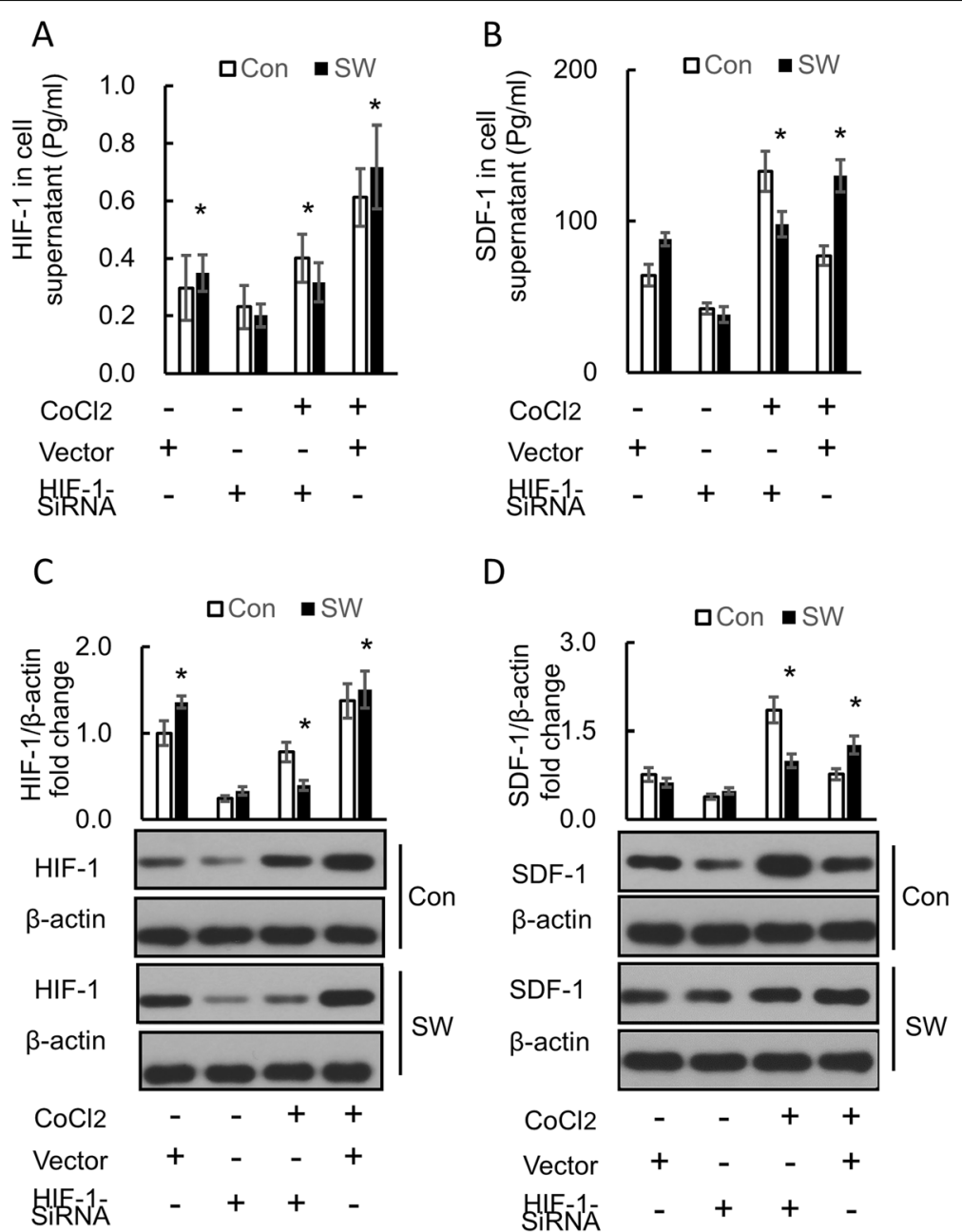

Fig. 6 Factors' expression in osteoblasts in vitro. Osteoblasts of SD rats were fed in four kinds of medium. Short-Wave irradiation was provided to the cells in the SW group. $\mathbf{a}, \mathbf{b}$ The concentration of HIF-1 and SDF-1 in the culture medium of osteoblasts was analyzed by ELISA. $\mathbf{c}$, $\mathbf{d}$ The expression of HIF-1 and SDF-1 in the osteoblasts was analyzed by western blot. Data represent mean \pm SD. Differences between the control group and the Short-Wave treatment group were assessed by performing a $t$ test. ${ }^{*} P<0.05$. Con control, SW Short-Wave treatment

\section{Short-Wave therapy promotes HIF-1 expression in osteoblasts in vitro}

We evaluated the HIF-1 in the culture medium fluid of osteoblasts under a Short-Wave in vitro by ELIS A. The results showed that the expression of HIF-1 significantly increased following Short-Wave treatment $(P=0.047)$, especially under $\mathrm{CoCl}_{2}$ stimulated hypoxic conditions $(P=0.018)$. Next, we collected the osteoblasts and measured the expression of HIF1 by western blot. We found a higher expression of HIF-1 after Short-Wave irradiation, both under normoxia $(P=0.021)$ and hypoxic condition $(P=0.046)$ (Fig. 6a, c). Also, the expression of SDF-1 in the medium improved following Short-Wave therapy under normoxia (Fig. 6b, d). HIF-1 $\alpha$-siRNA inhabited the HIF-1 expression. The expression of SDF-1 in osteoblasts and its concentration in culture media of osteoblasts was decreased after treating cells with HIF-1 $\alpha$-siRNA.

\section{The migratory effect of HIF-1 on MSC under Short-Wave irradiation}

As shown in Fig. 7, MSC cultured in normoxia with the medium fluid of SW-irradiated osteoblasts infected vector for $24 \mathrm{~h}$. At $48 \mathrm{~h}$, it showed higher migration compared to control cells cultured in the medium fluid without SW irradiation $(P<0.05)$. The same tendency was also seen in simulated hypoxic conditions at $24 \mathrm{~h}(P<0.05)$, but not at $48 \mathrm{~h}$. The results of the analysis are seen in Table 2 .

Additionally, to determine the effects of the HIF-1 in Short-Wave treatment on MSC migration, we used siRNA to inhibit HIF-1 in cultured osteoblasts. Briefly, siRNA reversed the above outcome (Fig. 7, Table 2). 


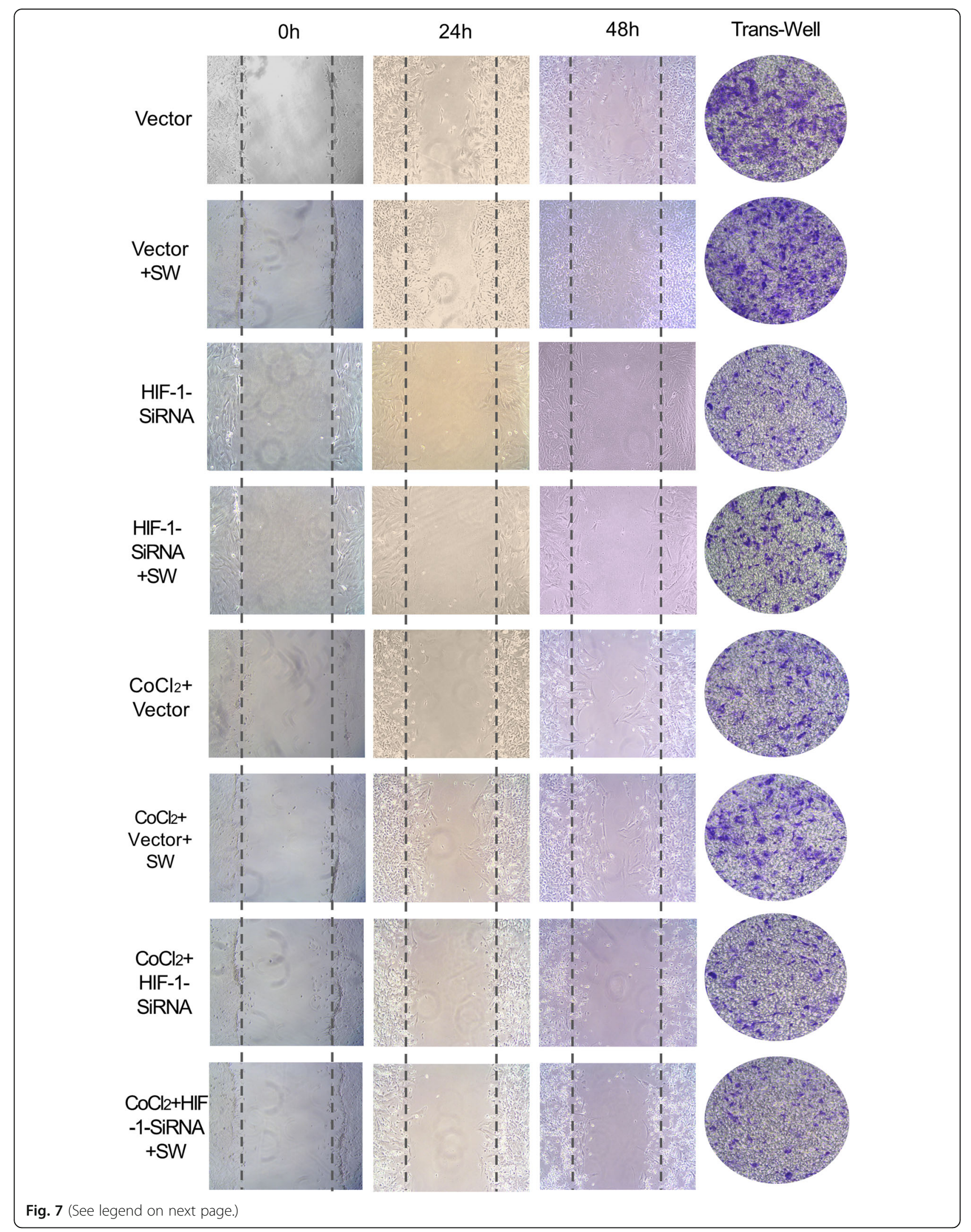


(See figure on previous page.)

Fig. 7 Migration in vitro. In wound healing assay, MSC (SD rat strain) was fed with 8 different kinds of osteoblast culture medium. Photographs were collected at $\mathbf{0}, 24$, and $48 \mathrm{~h}$. Additionally, the chemotactic effect of the culture medium of Short-Wave-irradiated osteoblasts on MSC in vitro analyzed by the trans-well assay. Eight kinds of osteoblast (SD rat strain) culture medium were seeded in the bottom chamber. The top chambers filled with MSC (SD rat strain) starved overnight were inserted. Twenty-four hours later, the cells that migrated to the bottom side

were accumulated

\section{Migration-correlation factor expression in MSC}

Next, we examined whether the medium fluid of osteoblasts irradiated by Short-Wave could affect the gene expression of con-cultured MSC. The gene expression of CXCR4, $\beta$-catenin, FAK, and F-actin in MSC were analyzed using q RT-PCR (Fig. 8a) and western blot (Fig. 8b, c). As a receptor, CXCR4 was increased under normoxia $(P=0.011)$ and under hypoxic conditions $(P=0.015)$. In addition, it decreased under HIF-1-inhabited medium both under normoxia $(P=0.900)$ and hypoxia $(P=$ 0.046). The Short-Wave-irradiation medium also provided a positive effect on the expression of $\beta$-catenin $(P=0.013)$ and F-actin $(P=0.031)$ in MSC under hypoxia; yet, no statistical difference was observed under normoxia (each $P>0.05$ ). The rise of $F$-actin and $\beta$ catenin were restrained since osteoblasts were transplanted in HIF-1 siRNA under normoxia and hypoxia (each $P>0.05$ ). Additionally, no statistical difference was observed in FAK between the two groups (each $P>$ 0.05). Nevertheless, phosphorylation levels of FAK were much higher in the Short-Wave group under normoxia $(P=0.040)$, which also decreased since MSC cultured in the medium of HIF-1 restrained osteoblasts (each $P>$ 0.05).

\section{Discussion}

The clinic application of high-frequency treatment can accelerate the resolution of hematoma and fracture healing. Nevertheless, the underlying mechanisms are not

Table 2 Migration test in vitro

\begin{tabular}{|c|c|c|c|}
\hline & \multicolumn{2}{|c|}{ Wound region (\%WR) } & \multirow{2}{*}{$\begin{array}{l}\text { Number } \\
\text { of } \\
\text { migrated } \\
\text { cells } 24 \mathrm{~h}\end{array}$} \\
\hline & $24 \mathrm{~h}$ & $48 \mathrm{~h}$ & \\
\hline Vector & $31.4 \pm 1.1$ & $19.8 \pm 0.8$ & $319 \pm 13$ \\
\hline Vector+SW & $27.7 \pm 1.5^{\mathrm{b}}$ & $8.84 \pm 1.3^{b}$ & $420 \pm 15^{b}$ \\
\hline Hif-1-SiRNA & $44.9 \pm 1.7$ & $38.7 \pm 3.7$ & $221 \pm 11$ \\
\hline Hif-1-SiRNA+SW & $46.1 \pm 1.4$ & $40.0 \pm 1.5$ & $229 \pm 12$ \\
\hline $\mathrm{CoCl}_{2}+$ Vector & $45.6 \pm 0.9$ & $32.2 \pm 3.0$ & $244 \pm 10$ \\
\hline $\mathrm{CoCl}_{2}+$ Vector+SW & $35.4 \pm 2.2^{c}$ & $33.8 \pm 3.4$ & $374 \pm 17^{c}$ \\
\hline $\mathrm{CoCl}_{2}+\mathrm{Hif-1-SiRNA}$ & $45.9 \pm 1.2$ & $42.6 \pm 1.7$ & $221 \pm 11$ \\
\hline $\mathrm{CoCl}_{2}+\mathrm{Hif}-1$-siRNA+SW & $43.7 \pm 1.6$ & $38.8 \pm 1.8$ & $207 \pm 13$ \\
\hline
\end{tabular}

${ }^{a} \% W R=$ (the size of the wound region/total size of image) $\times 100 .{ }^{b}$ Vector VS Vector+SW at the same time point $P<0.05 .{ }^{C} \mathrm{CoCl}_{2}+$ Vector VS

$\mathrm{CoCl}_{2}+$ Vector+SW at the same time point $P<0.05$ fully understood. Previously, it has been reported that fracture healing is associated with an increase in calcium phosphate mineral salt deposition, which occurs 2 to 4 weeks after injury [36, 37]. In this study, we found that high-frequency Short-Wave irradiation could promote the healing process, including the promotion of bony callus formation and the MSC migration. These healing characteristics were observed 1 to 3 weeks after the injury.

MSC has a vital role in the process of fracture healing [38]. The early stage of healing is mainly mediated by the biological actions of MSC [38]. Preclinical studies have suggested that transplanted exogenous or endogenous MSC can migrate to the fracture site after injury and restore the fracture callus volume and biomechanical properties of the bone in mice [39]. Injection of MSC by intravenous or intra-arterial infusion is commonly used to treat bone injury in mice. Yet, systemic administration has low therapeutic efficacy because only a small percentage of MSC can reach the target tissue $[40,41]$. Hence, one of the solutions to improve therapeutic efficacy is to promote MSC migration and homing.

So far, only a few studies have focused on investigating the MSC migration in the electric field, especially in the direct current electric field. Zimolag and Griffin have observed that in an external direct current electric field, MSC directly migrated toward the cathode [42, 43]. Moreover, Banks et al. have discovered that cells display a highly elongated phenotype conversion and consistent perpendicular alignment to the electric field vector accounting for the effects of electric field strength [44]. Furthermore, Liu and Zhao found that the applied electromagnetic field might be useful to control or enhance the migration of MSC during bone healing [45, 46]. Nevertheless, as a kind of high-frequency electrotherapy, areas of exposure could not be polarized by Short-Wave therapy, the migration of MSC might not be associated with field stress. Short-Wave therapy is generally used for thermal effects that provoke or enhance cellular activity resulting from energy-absorbing in oscillating electrical fields [47]. Previous studies have shown that thermal stress can modulate some molecules affected by hypoxia $[48,49]$. For example, HIF- $1 \alpha$, a transcription factor that is positively correlated with the acute temperature changes in organs, such as the brain, liver, kidney, and gonad tissues, can regulate the cellular 


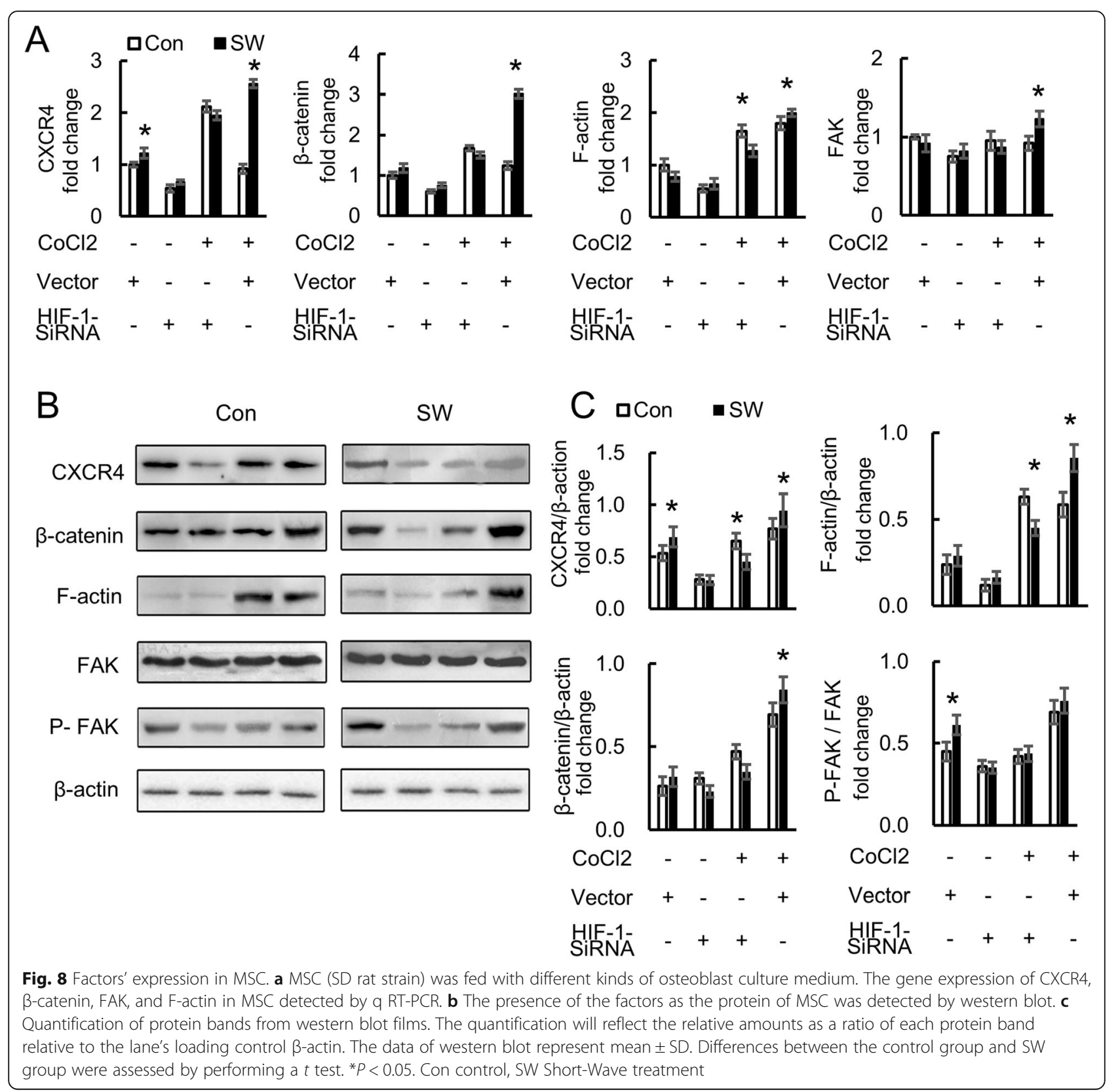

response to hypoxia stress [50] that is significantly increased in osteoblasts [51]. In the current study, we did not focus on the direct effect of Short-Wave on the migration of MSC in vitro. We found an increased expression of HIF-1 in callus and osteoblasts exposed to ShortWave therapy, which could be the chemokines for MSC to fracture area. Consequently, we assume that the regulation of the hypoxia pathway in callus affects MSC homing to promote tissue regeneration by Short-Wave. High expression of HIF-1a and BMP-2 promote the migration of MSC to the bone defect area [3]. Therefore, in several tissue engineering strategies, HIF stabilized biological materials are used to improve MSC migration and survival $[52,53]$. In this study, it was found that exogenous MSC homing increased in fractures exposed to Short-Wave irradiation in vivo. Besides, we discovered that the MSC migration was improved by the cultural medium of osteoblast exposed to Short-Wave therapy irradiation in vitro, which could be further enhanced in stimulated hypoxia in fracture and restrained by inhibiting HIF- $1 \alpha$ expression of culture osteoblasts. Therefore, we believe that HIF-1 is a key factor in the healing process activated by Short-Wave treatment. However, the effect of Short-Wave treatment on fracture healing of the HIF-1a inhibitor was not observed in vivo, which is a limitation of the current study. A research of HIF-1a 


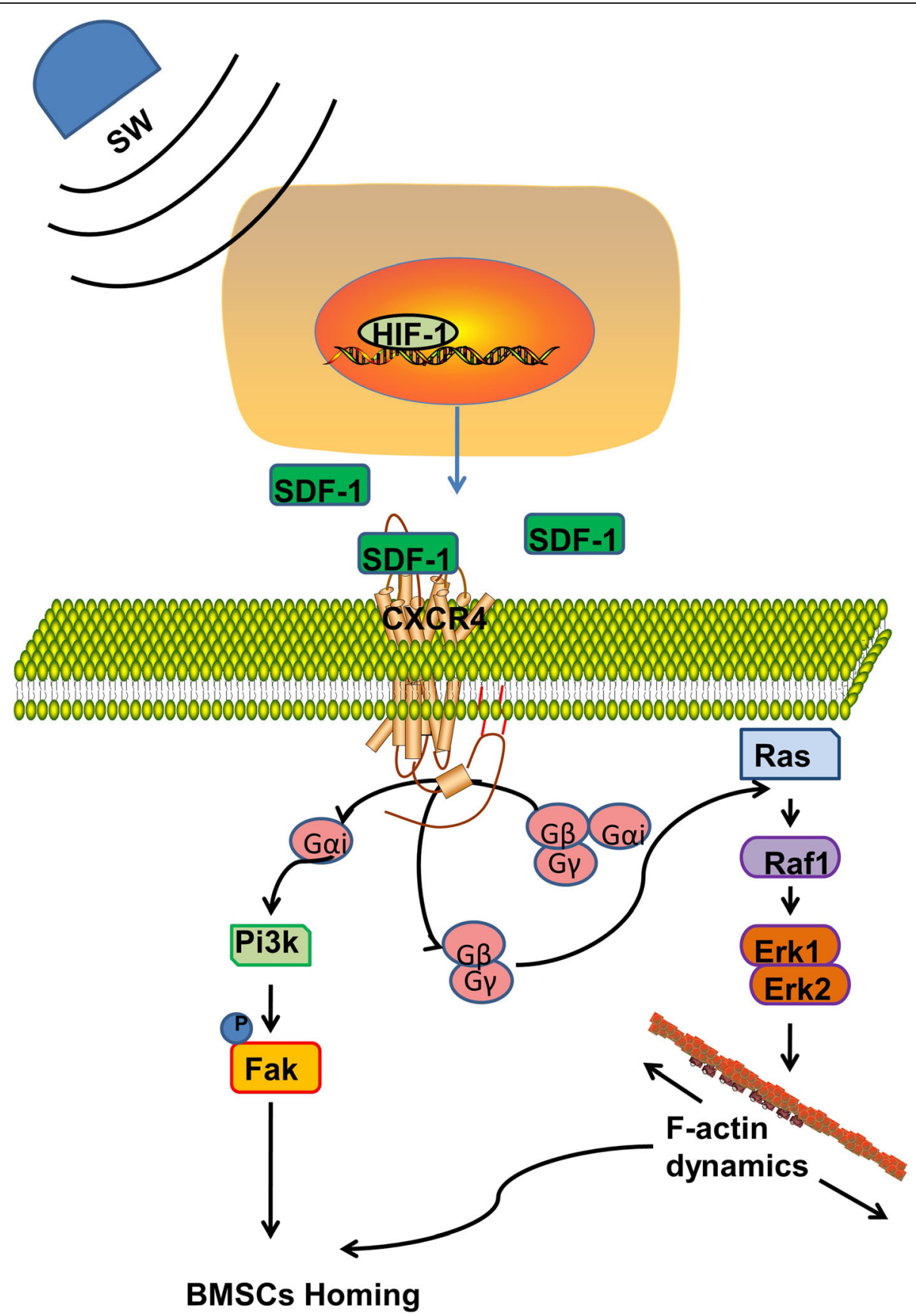

Fig. 9 Schematic diagram of Short-Waves promoting fracture healing by chasing HIF-1 and promoting MSC migration. SW Short-Wave treatment, HIF-1 hypoxia-inducible factor 1, SDF-1 stromal cell-derived factor 1, CXCR4 C-X-C motif receptor 4, PI3K phosphatidylinositol 3-kinase, Erk extracellular regulated protein kinases, FAK focal adhesion kinase, MSCs mesenchymal stem cells

conditional knockout rats of fracture with Short-Wave therapy will be conceived in the future.

The homing of CXCR4-positive progenitor cells in circulation is upregulated since the increase of HIF-1 induces SDF-1 expression. As a cell growth-stimulating factor, SDF-1 belongs to the CXC subfamily of chemokines $[54,55]$. SDF-1 can activate CXCR4, a G proteincoupled receptor [56]. Progenitor cell recruitment to injured tissues can be prevented if SDF-1 in ischemic tissue or CXCR4 on circulating cells were blockaded [54, 57]. In the bone marrow, discrete regions of the anoxic chamber have increased SDF-1 expression and progenitor cell tropism [58]. Over the last 10 years, numerous studies have confirmed that SDF-1/CXCR4 has a pivotal role in the biologic and physiologic functions of MSC [59]. In this study, we found increased expression of 
SDF-1 in callus and blood exposed to irradiation, which serves as a chemoattractant to recruit CXCR4-expressed MSC both in circulation and fracture site. FAK is the downstream protein kinase in the CXCR4 signaling cascade, which can integrate extracellular signaling and cellular migration [60]. Additionally, the cytoskeleton network partly detects the biomechanical characterization of living cells. It has been suggested that F-actin transmutation affects cell morphology and migration [61]. In the current study, the expression of Factin and phosphorylated FAK increased in the medium of cultured osteoblasts under Short-Wave irradiation. The migration of MSC was improved on the molecular level. Therefore, Short-Wave treatment enhanced the local chemotaxis for MSC in the fracture site, which might be the underlying mechanism (Fig. 9).

\section{Conclusion}

Short-Wave therapy could increase HIF-1 in callus, which is one of the crucial mechanisms of chemotaxis MSC homing in fracture healing.

\section{Abbreviations}

MSC: Mesenchymal stem cell; HIF: Hypoxia-inducible factor; SDF-1: Stromal cell-derived factor; CXCR: C-X-C chemokine receptor; FAK: Focal adhesion kinase; SW: Short-Wave therapy treatment group; Con: Control group; MG: MSC labeled by the GFP

\section{Acknowledgements}

We thank Dr. Yongxuan Wang, Dr. Dongdong Song, and Dr. Kai Kang for their outstanding technical assistance with radiographs. We also give our thanks to Professor Ruiping Zhu for her help with histopathology.

\section{Authors' contributions}

Conception and design: DMY and CC; implement:QWW, QZ, DMY, SL and HWL; analysis and interpretation of the data: CC and QZ; drafting of the article: DMY and CC; critical revision of the article for important intellectual content: CC and DMY; final approval of the article: all authors; statistical expertise: QZ and HWL; obtaining funding: DMY; and administrative, technical, or logistical support: DMY.

\section{Funding}

The National Natural Science Foundation of China (grant number 81601982) supported this study.

\section{Availability of data and materials}

The authors do not wish to share the data for the moment since further study is in progress.

\section{Ethics approval and consent to participate}

All animal studies (including the rat and mouse euthanasia procedure) were done in compliance with the regulations and guidelines of Affiliated Zhongshan Hospital of Dalian University institutional animal care.

\section{Consent for publication}

Not applicable.

\section{Competing interests}

The authors declare that they have no competing interests.

\section{Author details}

${ }^{1}$ Department of Rehabilitation, Affiliated Zhongshan Hospital of Dalian University, Dalian 116001, China. ${ }^{2}$ Department of Anatomy, Medical College of Dalian University, Dalian, China. ${ }^{3}$ Department of Rehabilitation, The people's Hospital of Longhua District, Shenzhen, China.
Received: 14 April 2020 Revised: 12 August 2020

Accepted: 17 August 2020 Published online: 07 September 2020

\section{References}

1. Benedetto S, Alessia F, Stefano M, et al. Self-renewing osteoprogenitors in bone marrow sinusoids can organize a hematopoietic microenvironment. Cell. 2007;131(2):324-36. https://doi.org/10.1016/j.cell.2007.08.025.

2. Kumar S, Ponnazhagan S. Mobilization of bone marrow mesenchymal stem cells in vivo augments bone healing in a mouse model of segmental bone defect. Bone. 2012;50(4):1012-8. https://doi.org/10.1016/j.bone.2012.01.027.

3. Yueyi $\mathrm{C}$, Xiaoguang $\mathrm{H}$, Jingying $\mathrm{W}$, et al. Calvarial defect healing by recruitment of autogenous osteogenic stem cells using locally applied simvastatin. Biomaterials. 34(37):9373-80. https://doi.org/10.1016/j. biomaterials.2013.08.060.

4. Wu Y, Zhao RC. The role of chemokines in mesenchymal stem cell homing to myocardium. Stem Cell Rev Rep. 2012;8(1):243-50. https://doi.org/10. 1007/s12015-011-9293-z.

5. Kim YS, Noh MY, Kim JY, et al. Direct GSK-3ß inhibition enhances mesenchymal stromal cell migration by increasing expression of beta-PIX and CXCR4. Mol Neurobiol. 2013. https://doi.org/10.1007/s12035-012-8393-3.

6. Li-Kai T, Zhifei $W$, Jeeva $M$, et al. Mesenchymal stem cells primed with valproate and lithium robustly migrate to infarcted regions and facilitate recovery in a stroke model. Stroke. 2011;42(10):2932-9. https://doi.org/10. 1161/STROKEAHA.110.612788.

7. Moisley KM, El-Jawhari JJ, Owston $\mathrm{H}$, et al. Optimising proliferation and migration of mesenchymal stem cells using platelet products: a rational approach to bone regeneration. J Orthop Res. 2019;37(6):1329-38. https:// doi.org/10.1002/jor.24261.

8. Lin F, Zhu Y, Hu G. Naringin promotes cellular chemokine synthesis and potentiates mesenchymal stromal cell migration via the Ras signaling pathway. Exp Ther Med. 2018;16(4):3504-10. https://doi.org/10.3892/etm. 2018.6634 .

9. Annabi B, Lee YT, Turcotte $S$, et al. Hypoxia promotes murine bone-marrowderived stromal cell migration and tube formation. Stem Cells. 2010;21(3): 337-47. https://doi.org/10.1634/stemcells.21-3-337.

10. Liu H, Xue W, Ge G, et al. Hypoxic preconditioning advances CXCR4 and CXCR7 expression by activating HIF-1a in MSCs. Biochem Biophysical Research Communications. 2010;401(4):509-15. https://doi.org/10.1016/j. bbrc.2010.09.076.

11. Xu H, Feng L, Zeng Z, and Xu S, Experimental study on ultrashort wave therapy on the healing of fracture. Hunan Yi Ke Da Xue Xue Bao, 1999. 24(2): 125-127.

12. Wang GJ and Liu J, [Clinical randomized controlled trial on ultrashort wave and magnetic therapy for the treatment of early stage distal radius fractures]. Zhongguo Gu Shang, 2012;25(7):572-5.

13. Dewhirst MW, Viglianti BL, Lora-Michiels M, Hanson M, Hoopes PJ. Basic principles of thermal dosimetry and thermal thresholds for tissue damage from hyperthermia. Int J Hyperth. 2003;19(3):267-94. https://doi.org/10.1080/ 0265673031000119006.

14. Sekins KM, Lehmann JF, Esselman $P$, et al. Local muscle blood flow and temperature responses to $915 \mathrm{MHz}$ diathermy as simultaneously measured and numerically predicted. Arch Phys Med Rehabil. 1984;65(1):1-7.

15. Yatvin MB. The influence of membrane lipid composition and procaine on hyperthermic death of cells. Int J Radiation Biol Related Stud Physics Chem Med. 1977;32(6):513-21.

16. Chen, Ningning, Kang, Renquan, and Zhang, Insufficient radiofrequency ablation promotes the growth of non-small cell lung cancer cells through PI3K/Akt/HIF-1a signals. Acta Biochim Biophys Sin, 2016;48(4):371-7. https:// doi.org/10.1093/abbs/gmw005.

17. Guo XQ, Qi L, Yang J, et al. Salidroside accelerates fracture healing through cell-autonomous and non-autonomous effects on osteoblasts. Cell Tissue Res. 2017;367(2):197-211. https://doi.org/10.1007/s00441-016-2535-2.

18. Martinez VG, Ontoria-Oviedo I, Ricardo CP, et al. Overexpression of hypoxiainducible factor 1 alpha improves immunomodulation by dental mesenchymal stem cells. Stem Cell Res Ther. 2017;8(1):208. https://doi.org/ 10.1186/s13287-017-0659-2.

19. Ishii M, Takahashi M, Murakami J, Yanagisawa T, Nishimura M. Vascular endothelial growth factor-C promotes human mesenchymal stem cell migration via an ERK-and FAK-dependent mechanism. Mol Cell Biochem. 2019;455(1-2):185-93. https://doi.org/10.1007/s11010-018-3481-y. 
20. Meng SS, Xu XP, Chang W, et al. LincRNA-p21 promotes mesenchymal stem cell migration capacity and survival through hypoxic preconditioning. Stem Cell Res Ther. 2018;9(1):280. https://doi.org/10.1186/s13287-018-1031-x.

21. Chen JQ, Huang LH. Advances of researchs on molecular mechanisms of mesenchymal stem cells and their exosomes in angiogenesis--review. Zhongguo Shi Yan Xue Ye Xue Za Zhi. 2018;26(6):1858-62. https://doi.org/ 10.7534/j.issn.1009-2137.2018.06.047

22. Fuseler JW, Valarmathi MT. Modulation of the migration and differentiation potential of adult bone marrow stromal stem cells by nitric oxide. Biomaterials. 2012;33(4):1032-43. https://doi.org/10.1016/j.biomaterials.2011.10.029.

23. Yun Feng R, Lui PPY, Gang L, et al. Isolation and characterization of multipotent rat tendon-derived stem cells. Tissue Eng Part A. 2010;16(5): 1549-58. https://doi.org/10.1089/ten.tea.2009.0529.

24. Wei FY, Kwok-Sui L, Gang L, et al. Low intensity pulsed ultrasound enhanced mesenchymal stem cell recruitment through stromal derived factor-1 signaling in fracture healing. Plos One. 9(9):e106722. https://doi.org/ 10.1371/journal.pone.0106722.

25. Granero-Molto F, Weis JA, Miga Ml, et al. Regenerative effects of transplanted mesenchymal stem cells in fracture healing. Stem Cells. 2009; 27(8):1887-98. https://doi.org/10.1002/stem.103.

26. Pang $C-J$, Tong $L$, Ji L- $L$, et al. Synergistic effects of ultrashort wave and bone marrow stromal cells on nerve regeneration with acellular nerve allografts. Synapse. 2013;67(10):637-47. https://doi.org/10.1002/syn.21669.

27. Liu YZ, Akhter MP, Gao X, et al. Glucocorticoid-induced delayed fracture healing and impaired bone biomechanical properties in mice. Clin Interv Aging. 2018;13:1465-74. https://doi.org/10.2147/CIA.S167431.

28. Freeman TA, Patel P, Parvizi J, Antoci V Jr, Shapiro IM. Micro-CT analysis with multiple thresholds allows detection of bone formation and resorption during ultrasound-treated fracture healing. J Orthop Res. 2009;27(5):673-9. https://doi.org/10.1002/jor.20771.

29. Mediero A, Perez-Aso M, Wilder T, Cronstein BN. Brief report: methotrexate prevents wear particle-induced inflammatory osteolysis in mice via activation of adenosine A2A receptor. Arthritis Rheumatol. 2015;67(3):84955. https://doi.org/10.1002/art.38971.

30. Sotkis A, Wang XG, Yasumura T, et al. Calmodulin colocalizes with connexins and plays a direct role in gap junction channel gating. Cell Commun Adhes. 2001;8(4-6):277-81. https://doi.org/10.3109/ 15419060109080737.

31. Herberg S, Fulzele S, Yang $N$, et al. Stromal cell-derived factor-1 beta potentiates bone morphogenetic protein-2-stimulated osteoinduction of genetically engineered bone marrow-derived mesenchymal stem cells in vitro. Tissue Eng A. 2013;19(1-2):1-13. https://doi.org/10.1089/ten.tea.2012. 0085.

32. Schmittgen TD, Livak KJ. Analyzing real-time PCR data by the comparative C-T method. Nat Protoc. 2008;3(6):1101-8. https://doi.org/10.1038/nprot.2008.73.

33. Mattinzoli D, Messa P, Corbelli A, et al. Application of retinoic acid to obtain osteocytes cultures from primary mouse osteoblasts. J Vis Exp. 2014;(87): 51465. https://doi.org/10.3791/51465.

34. Periyasamy-Thandavan $\mathrm{S}$, Jiang $\mathrm{M}$, Wei $\mathrm{Q}$, et al. Autophagy is cytoprotective during cisplatin injury of renal proximal tubular cells. Kidney Int. 2008;74(5): 631-40. https://doi.org/10.1038/ki.2008.214.

35. Liu T, Zou W, Shi G, et al. Hypoxia-induced MTA1 promotes MC3T3 osteoblast growth but suppresses MC3T3 osteoblast differentiation. Eur J Med Res. 2015;20(1):1-7. https://doi.org/10.1186/s40001-015-0084-X.

36. Leon SA, Asbell SO, Edelstein $\mathrm{G}$, et al. Effects of hyperthermia on bone. I. Heating rate patterns induced by microwave irradiation in bone and muscle phantoms. Int J Hyperth. 1993;9(1):69-75. https://doi.org/10.3109/ 02656739309061479

37. Leon SA, Asbell SO, Arastu HH, et al. Effects of hyperthermia on bone. II. Heating of bone in vivo and stimulation of bone growth. Int J Hyperth. 1993;9(1):77-87. https://doi.org/10.3109/02656739309061480.

38. Ito $\mathrm{H}$. Chemokines in mesenchymal stem cell therapy for bone repair: a novel concept of recruiting mesenchymal stem cells and the possible cell sources. Mod Rheumatol. 2011;21(2):113-21. https://doi.org/10.1007/s10165010-0357-8.

39. Obermeyer TS, David $Y$, Kristen $L$, et al. Mesenchymal stem cells facilitate fracture repair in an alcohol-induced impaired healing model. J Orthop Trauma. 2012;26(12):712. https://doi.org/10.1097/bot.0b013e3182724298.

40. De Becker A, Van Riet I. Homing and migration of mesenchymal stromal cells: how to improve the efficacy of cell therapy? World J Stem Cells. 2016; 8(3):73-87. https://doi.org/10.4252/wjsc.v8.i3.73.
41. Su P, Tian $Y$, Yang $C$, et al. Mesenchymal stem cell migration during bone formation and bone diseases therapy. Int J Mol Sci. 2018;19(8):2343. https:// doi.org/10.3390/ijms19082343.

42. Zimolag E, Borowczyk-Michalowska J, Kedracka-Krok S, et al. Electric field as a potential directional cue in homing of bone marrow-derived mesenchymal stem cells to cutaneous wounds. Biochim Biophys Acta Mol Cell Res. 2017;1864(2):267-79. https://doi.org/10.1016/j.bbamcr.2016. 11.011 .

43. Griffin M, Iqbal SA, Sebastian A, Colthurst J, Bayat A. Degenerate wave and capacitive coupling increase human MSC invasion and proliferation while reducing cytotoxicity in an in vitro wound healing model. PLoS One. 2011;6(8):e23404. https://doi.org/10.1371/journal. pone.0023404.

44. Banks TA, Luckman PS, Frith JE, Cooper-White JJ. Effects of electric fields on human mesenchymal stem cell behaviour and morphology using a novel multichannel device. Integr Biol (Camb). 2015;7(6):693-712. https://doi.org/ 10.1039/c4ib00297k.

45. Liu L, Yu Q, Hu K, et al. Electro-acupuncture promotes endogenous multipotential mesenchymal stem cell mobilization into the peripheral blood. Cell Physiol Biochem. 2016;38(4):1605-17. https://doi.org/10.1159/ 000443101.

46. Zhao Z, Watt C, Karystinou A, et al. Directed migration of human bone marrow mesenchymal stem cells in a physiological direct current electric field. Eur Cell Mater. 2011;22:344-58. https://doi.org/10.22203/ecm.v022a26.

47. Shields N, Gormley J, O'Hare N. Short-wave diathermy: current clinical and safety practices. Physiother Res Int. 2002;7(4):191-202. https://doi.org/10. 1002/pri.259.

48. Ostberg JR, Repasky EA. Emerging evidence indicates that physiologically relevant thermal stress regulates dendritic cell function. Cancer Immunol Immunother. 2005;55(3):292-8. https://doi.org/10.1007/s00262-005-0689-y.

49. Ostberg JR, Patel R, Repasky EA. Regulation of immune activity by mild (fever-range) whole body hyperthermia: effects on epidermal Langerhans cells. Cell Stress Chaperones. 2000;5(5):458. https://doi.org/10.1379/14661268(2000)005<0458:roiabm>2.0.co;2

50. Riddle SR, Ahmad A, Ahmad S, Deeb SS, and White CW, Hypoxia induces hexokinase II gene expression in human lung cell line A549. Am J Physio Lung Cell Mole Physiol, 2000;278(2):L407-L416. https://doi.org/10.1152/ ajplung.2000.278.2.L407.

51. Zhou M, Lu S, Lu G, et al. Effects of remote ischemic postconditioning on fracture healing in rats. Mol Med Rep. 2017;15(5):3186-92. https://doi.org/10. 3892/mmr.2017.6348.

52. Azevedo MM, Tsigkou O, Nair R, et al. Hypoxia inducible factor-stabilizing bioactive glasses for directing mesenchymal stem cell behavior. Tissue Eng Part A. 2015;21(1-2):382-9. https://doi.org/10.1089/ten.TEA.2014.0083.

53. Yu X, LU C, Liu H, et al. Hypoxic preconditioning with cobalt of bone marrow mesenchymal stem cells improves cell migration and enhances therapy for treatment of ischemic acute kidney injury. PLoS One. 2013;8(5): e62703. https://doi.org/10.1371/journal.pone.0062703.

54. Ceradini DJ, Kulkarni AR, Callaghan MJ, et al. Progenitor cell trafficking is regulated by hypoxic gradients through HIF-1 induction of SDF-1. Nat Med. 2004;10(8):858-64. https://doi.org/10.1038/nm1075.

55. Kitaori T, Ito H, Schwarz EM, et al. Stromal cell-derived factor 1/CXCR4 signaling is critical for the recruitment of mesenchymal stem cells to the fracture site during skeletal repair in a mouse model. Arthritis Rheum. 2009; 60(3):813-23. https://doi.org/10.1002/art.24330.

56. Mannavola F, Tucci M, Felici C, Passarelli A, Silvestris F. Tumor-derived exosomes promote the in vitro osteotropism of melanoma cells by activating the SDF-1/CXCR4/CXCR7 axis. J Transl Med. 2019;17(1):230. https://doi.org/10.1186/s12967-019-1982-4.

57. Sangani R, Pandya CD, Bhattacharyya MH, et al. Knockdown of SVCT2 impairs in-vitro cell attachment, migration and wound healing in bone marrow stromal cells. Stem Cell Res. 2014;12(2):354-63. https://doi.org/10. 1016/j.scr.2013.11.002.

58. Cotoia A, Mirabella L, Altamura S, et al. Circulating stem cells, HIF-1, and SDF-1 in septic abdominal surgical patients: randomized controlled study protocol. Trials. 2018;19(1):179. https://doi.org/10.1186/s13063-0182556-0.

59. Wei FY, Chow SK, Leung KS, et al. Low-magnitude high-frequency vibration enhanced mesenchymal stem cell recruitment in osteoporotic fracture healing through the SDF-1/CXCR4 pathway. Eur Cells Materials. 2016;31: 341-54. https://doi.org/10.22203/eCM.v031a22. 
60. Ning W, Ping YS, Xiaohuan G, et al. Delayed intranasal delivery of hypoxicpreconditioned bone marrow mesenchymal stem cells enhanced cell homing and therapeutic benefits after ischemic stroke in mice. Cell Transplant. 2013;22(6):977-91. https://doi.org/10.3727/096368912X657251.

61. Chen $\mathrm{Q}$, Liang $\mathrm{Q}$, Zhuang $\mathrm{W}$, et al. Tenocyte proliferation and migration promoted by rat bone marrow mesenchymal stem cell-derived conditioned medium. Biotechnol Lett. 2018;40(1):215-24. https://doi.org/10.1007/s10529017-2446-7.

\section{Publisher's Note}

Springer Nature remains neutral with regard to jurisdictional claims in published maps and institutional affiliations.

- fast, convenient online submission

- thorough peer review by experienced researchers in your field

- rapid publication on acceptance

- support for research data, including large and complex data types

- gold Open Access which fosters wider collaboration and increased citations

- maximum visibility for your research: over $100 \mathrm{M}$ website views per year

At $\mathrm{BMC}$, research is always in progress. 